\title{
The Effect of Quercus coccifera L. Extract on the Necrosis of Random-pattern Skin Flaps in Rats
}

\section{Quercus coccifera L. Ekstresinin Random Patern Deri Flebi Nekrozu Üzerine Etkisi}

\author{
๑ Erkan Orhan, ๑ ilsun Özkaya Aka*, ๑ Merve Yüzbaşığlu** , ๑ Burçin Yavuz**, \\ ๑ Erem Bilensoy**, ๑ Ayşe Kuruüzüm Uz ${ }^{* *}$ \\ Gaziantep University, Department of Plastic Surgery, Gaziantep, Turkey \\ * Sakarya Training and Research Hospital, Clinic of Plastic Surgery, Sakarya, Turkey \\ **Hacettepe University, Department of Pharmacology, Ankara, Turkey
}

Abstract

Aim: Ischemia-reperfusion injury is an important cause of flap loss. We investigated effects of Quercus coccifera L. extract known to have anti-oxidant and anti-inflammatory activity on skin flap viability.

Methods: Eighteen Wistar rats were used. Random-pattern skin flaps, $9 \times 3 \mathrm{~cm}$ in size, were applied on rats back and then the rats were divided into three groups. Following surgery, 2 cc of nitrofurazone cream and 2 cc of $Q$. coccifera $L$. water extract were applied daily in groups 2 and 3, respectively. Group 1 received no treatment after surgery. The percentage of necrosis on the flaps was calculated and histopathological examination of the tissue samples was made on day 7.

Results: The mean percentage of necrosis was $44.7 \%, 42.5 \%$ and $21.8 \%$ group 1,2 and 3 , respectively. The percentage of necrosis was statistically significantly lower in group 3 than in groups 1 and 2 ( $p<0.001$ and $p<0.00$, respectively). Neutrophil score was found to be significantly lower in group 3 than in groups 1 and 2 ( $p=0.002$ and $p=0.002$, respectively).

Conclusions: Necrosis of skin flaps was decreased through application of Q. coccifera extracts

Keywords: Quercus coccifera L., necrosis, skin flap
Amaç: İskemi-reperfüzyon hasarı önemli bir flep kaybı nedenidir. Bu çalışmada antioksidan ve antiinflamatuvar aktivitesi olduğu bilinen Quercus coccifera ekstresinin flep yaşayabilirliği üzerindeki etkisi incelenmiştir

Yöntemler: On sekiz Wistar cinsi sıçan kullanıldı. Sıçanların sırt bölgesinde $9 \times 3 \mathrm{~cm}$ 'lik random patern deri flebi kaldırıldı ve daha sonra flep tekrar aynı yere iade edildi. Daha sonra ratlar üç gruba ayrıldı. Grup 2'deki sıçanların sırtlarına günde bir defa 2 cc nitrofurazon krem, grup 3'teki sıçanların sırtına ise günde bir defa 2 cc Q. coccifera ektresi uygulandı. Grup 1'deki sıçanlara flep cerrahisi dışında bir işlem yapılmadı. Flep cerrahisinden 7 gün sonra fleplerdeki nekroz miktarı hesaplandı ve doku örnekleri alınarak histopatolojik inceleme yapıldı

Bulgular: Grup 1'de ortalama nekroz miktarı \%44,1, grup 2'de $\% 42,5$ ve grup 3'de \%21,8 olarak hesaplandı. Grup 3'deki nekroz miktarı, grup 1 ve grup $2^{\prime}$ den istatistiksel olarak anlamlı olacak şekilde az olduğu tespit edildi ( $p<0,001, p<0,001)$. Nötrofil skoru da grup 3 'de, grup 1 ve grup 2'ye göre istatistiksel olarak anlamlı olacak şekilde az bulundu. ( $p=0,002$ ve $p=0,002)$

Sonuç: $Q$. coccifera ekstresi uygulanması ile fleplerdeki nekroz miktarı azalmaktadır.

Anahtar Sözcükler: Quercus coccifera L., nekroz, deri flebi 


\section{Introduction}

Random-pattern skin flaps are commonly used in plastic surgery. Partial or complete flap loss continues to be a serious cause of morbidity despite advances in surgical techniques and new technologies (1).

One of the principal causes of flap loss is ischemiareperfusion (IR) injury. In ischemia, blood supply to a certain tissue region is insufficient, and extended ischemia results in necrosis. If reperfusion is achieved before necrosis, several physiopathological events occur which are first reversible and then become irreversible, leading to IR injury. Its causes include reactive oxygen species (ROS), inflammation and neutrophil chemotaxis, decreased nitric oxide (NO), and apoptosis (2).

No clinically usable therapeutic treatment for IR injury has been developed yet despite a number of experiments to increase flap viability with sympatholytics, vasodilators, prostaglandin inhibitors, glucocorticoids, anticoagulants, and many pharmacological agents with free-radical scavenging effects (3).

Quercus coccifera $L$. is a tall shrub native to the Mediterranean region of Anatolia, Turkey (2-4). Quercus species are used in local traditional medicine as an antiseptic, antidiarrheal, hemostatic, to heal wounds, to protect the cardiovascular system, and to aid digestion. Antiinşammatory and antioxidant effects have been reported for some species of Quercus, e.g. in our previous study, which showed anti-oxidant activity for water extracts of $Q$. coccifera stems (5-6).

In this study, our hypothesis is that $Q$. coccifera water (QWC) extract reduces IR flap damage through antioxidant and anti-inşammatory activity. We tested the effects of QWC extracts on the viability of random-pattern skin flaps in rats.

\section{Methods}

The Local Ethics Committee for Experimental Animals of Ankara University approved the study, and no informed consent was obtained due to the study was experimental. Twenty-four Wistar Albino female rats of 250 to $350 \mathrm{~g}$ were raised in the Production and Research Laboratory of Experimental Animals of Ankara University and used for this study.

All surgical procedures were performed by the same surgeon under sterile conditions and under anesthesia with $10 \%$ ketamine $\mathrm{HCl}\left(50 \mathrm{mg} / \mathrm{kg}\right.$, Alfamine $\left.{ }^{\circledR} \mathrm{IM}\right)$ and xylazine $\mathrm{HCl}\left(2.5 \mathrm{mg} / \mathrm{kg}\right.$, Rompun $\left.{ }^{\circledR} \mathrm{IM}\right)$. The rats were kept in separate cages, at $20^{\circ} \mathrm{C}$, and with 12 -hour periods of light and dark. They were fed the standard diet with no water restriction.

Plant Material: Quercus coccifera L. was collected from Sertavul-Akçeşme (South-central Anatolia, Turkey) and was identified by Prof. Zeki Aytaç from Gazi University. It was deposited and labeled HUEF 10003 in the Herbarium of Hacettepe University.

Water extraction: $Q$. coccifera stems with bark (50 g) were air-dried, powdered, and extracted with distilled water $(2 \times 500 \mathrm{~mL})$ at $100{ }^{\circ} \mathrm{C}$ for 3 hours. The extracts were dried in vacuum and lyophilized [Quasi-Continuous-Wave (QCW)-4 g, 8\%].

Preparation of Ointment: Hydrophilic Ointments with $1 \%$ QCW extract were prepared with the USP method. The following ingredients were accurately weighed: 0.025 $\mathrm{g}$ methylparaben, $0.015 \mathrm{~g}$ propylparaben, $1 \mathrm{~g}$ sodium lauryl sulfate, and $12 \mathrm{~g}$ propylene glycol. They were then dissolved in $37 \mathrm{~g}$ of water warmed to $75^{\circ} \mathrm{C}$ in a steam bath. Next, $1 \mathrm{~g}$ of QCW extract was added to the mixture and stirred continuously until it became homogeneous. Afterward, we weighed $25 \mathrm{~g}$ stearyl alcohol and 25 $\mathrm{g}$ white petrolatum, melted them in a steam bath, and warmed the mixture to $75{ }^{\circ} \mathrm{C}$. The previously mixed ingredients were stirred until the mixture congealed into a cold cream. For the control group, the same ointment was prepared, but $1 \mathrm{~g}$ nitrofurazone (Furacin ${ }^{\circledR}$ ) was added instead of the QCW extract (7).

\section{Surgical Method}

After anesthesia was administered, the animals were fixed in the prone position, and their back was shaved. The surgical site was cleaned with $10 \%$ povidone-iodine and covered sterilely. From the back of the rats, a $9 \times 3$ $\mathrm{cm}$ random-pattern skin flap with the panniculus carnosus was elevated. The flaps were then sutured to the same area with 4/0 Vicryl (8).

After surgery, the animals were divided into three groups of six animals each.

Group 1 (only surgery group): No substance was applied to the flap following surgery.

Group 2 (nitrofurazone group): Two cc of nitrofurazone ointment was applied daily to the flap.

Group 3 (QCW group): Two cc of QCW ointment was applied daily on the flap.

Following topical applications, the flaps were covered with a film layer (Tegaderm ${ }^{\circledR}$ ).

On the seventh postoperative day, the rats were euthanized with high-dose of anesthesia. Flap necrosis was quantified, and then tissue samples were taken for histopathological examination.

\section{Estimating Necrotic Area of Skin Flaps}

After the rats were euthanized, photographs of the flaps were taken at a resolution of 5 megapixels (1024×768 pixels) using a Sony DSC-W70 camera from the same distance. The total flap area and necrotic area were calculated using the program Adobe Photoshop 
CS5 (Adobe Systems, Inc., San Jose, CA). The areas were marked on the image and calculated in pixels. The necrotic area was estimated as a percentage of the total flap area (9).

\section{Histopathological Examination}

$1 \times 1 \mathrm{~cm}$ tissue biopsy specimens were taken $0.5 \mathrm{~cm}$ behind the necrosis line on the seventh postoperative day. They were fixed in $10 \%$ formaldehyde and embedded in paraffin blocks. 4- $\mu \mathrm{m}$ sections were removed and dyed with hematoxylin-eosin (H\&E) stain and examined under a light microscope. The specimens were evaluated based on polymorphonuclear cells and vascular proliferation was scored as: $0=a b s e n t, 1=$ mild, 2=intermediate, and $3=$ marked.

\section{Statistical Analyses}

Data were analyzed using SPSS 11.5 for Windows. For flap necrosis area, values are presented as group means \pm standard deviations, which were compared with one-way ANOVA. For the histopathological scores, group values are presented as minimum, median, and maximum and were compared with the Kruskal-Wallis test. Significant differences were further evaluated with post-hoc Tukey's test or Bonferroni adjusted Mann-Whitney's U test to identify the responsible factors. The significance level was $p<0.05$.
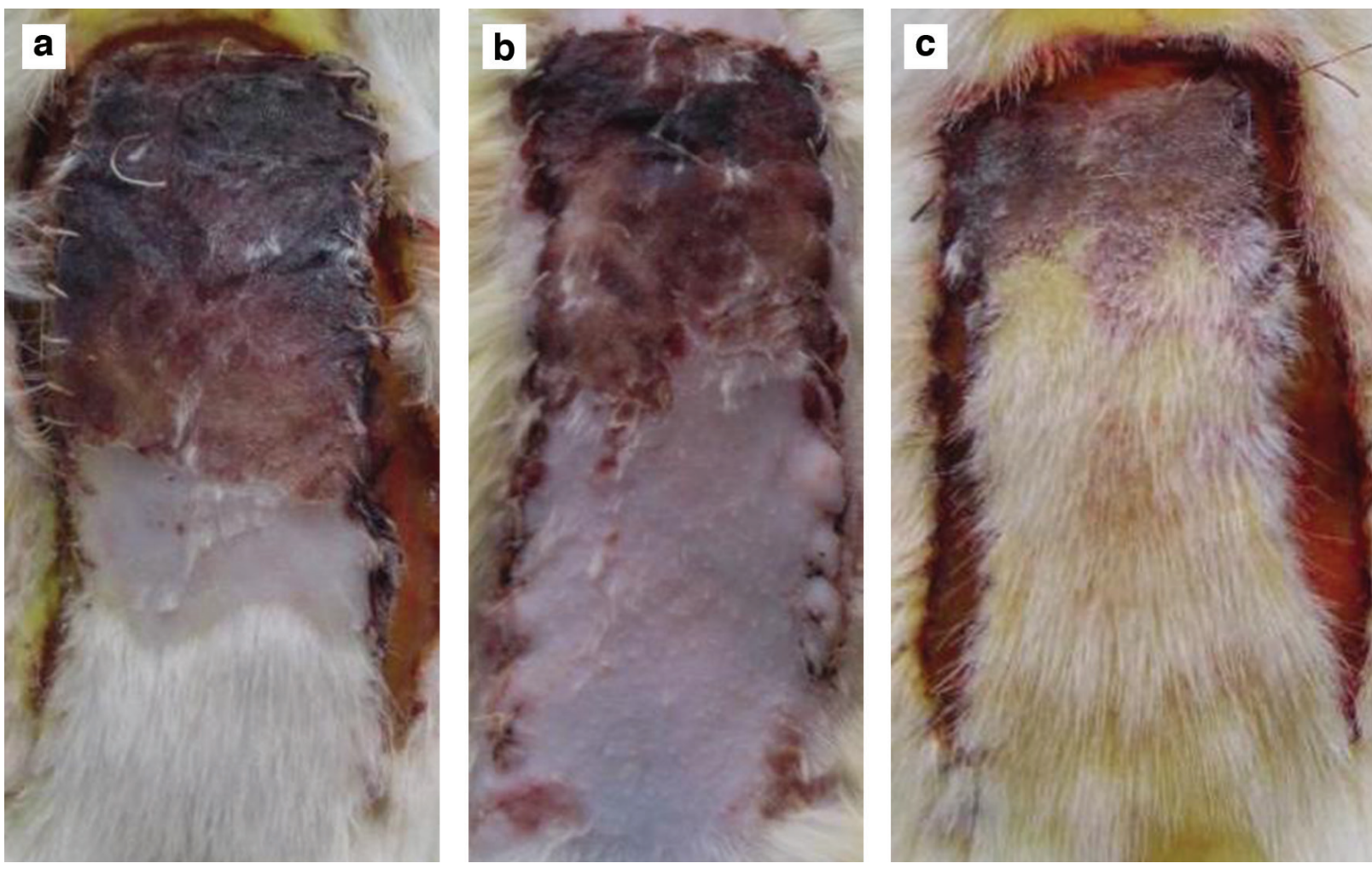

Figure 1. View of necrosis of the flaps. a. group 1 (only flap group), b. group 2 (nitrofurazone group), c. group 3 (QCW group)

\section{Results}

\section{Comparison of the Necrotic Areas of the Flaps}

The mean percentage of the necrotic tissue was $44.7 \%$ in group 1, $42.5 \%$ in group 2, and $21.8 \%$ in group. The percentage of necrotic area in group 3, which received QCW treatment, was significantly lower compared to both groups 1 and 2 ( $p<0.001)$. There was no significant difference between these two groups (Table 1, Figure 1,2). Histopathology scores were also statistically significantly lower in group 3 ( $p=0.002$, Table 2 , Figure 3$)$.

\section{Discussion}

In the caudal-based random-pattern skin flap model used in the present study, no tissue loss occurred in the region close to the pedicle because of sufficient perfusion.

\begin{tabular}{|l|l|}
\hline \multicolumn{2}{|l|}{ Table 1. Flap-necrosis areas by the groups } \\
\hline & $\begin{array}{l}\text { Necrosis rate (\%) } \\
\text { Mean } \pm \text { SD }\end{array}$ \\
\hline Group 1 (control group) & $44.7 \pm 3.0^{\mathrm{a}}$ \\
\hline Group 2 (Vaseline group) & $42.5 \pm 8.4 \mathrm{~b}$ \\
\hline Group 3 (QCW group) & $21.8 \pm 5.9^{\mathrm{a}, \mathrm{b}}$ \\
\hline $\begin{array}{l}\text { SD: Standard deviation, QCW: Q. coccifera water } \\
\text { aStatistically significant difference between group 3 (QCW group) and group } 1 \\
\text { (control group) (p<0.001); bStatistically significant difference between the group } \\
\text { 2 (Vaseline group) and group 3 (QCW) (p<0.001) }\end{array}$ \\
\hline
\end{tabular}




\begin{tabular}{|c|c|c|}
\hline & $\begin{array}{l}\text { Polymorphonuclear } \\
\text { leukocyte } \\
\text { (median) }\end{array}$ & $\begin{array}{l}\text { Vascular } \\
\text { proliferation } \\
\text { (median) }\end{array}$ \\
\hline Group 1 (control group) & $3^{a}$ & 1 \\
\hline Group 2 (Vaseline) & $2^{b}$ & 1 \\
\hline Group 3 (QCW) & $0.5^{a, b}$ & 1.5 \\
\hline \multicolumn{3}{|c|}{$\begin{array}{l}\text { QCW: Q. coccifera water } \\
\text { aStatistically significant difference between the group } 3 \text { (QCW group) and } \\
\text { group } 1 \text { (control group) ( } p=0.002) \text {; bStatistically significant difference between } \\
\text { the group } 3 \text { (QCW group) and group } 2 \text { (Vaseline group) }(p=0.002 \text { ) } \\
\text { (0=Absent, } 1=\text { Mild, } 2=\text { Intermediate, and } 3=\text { Marked.) }\end{array}$} \\
\hline
\end{tabular}

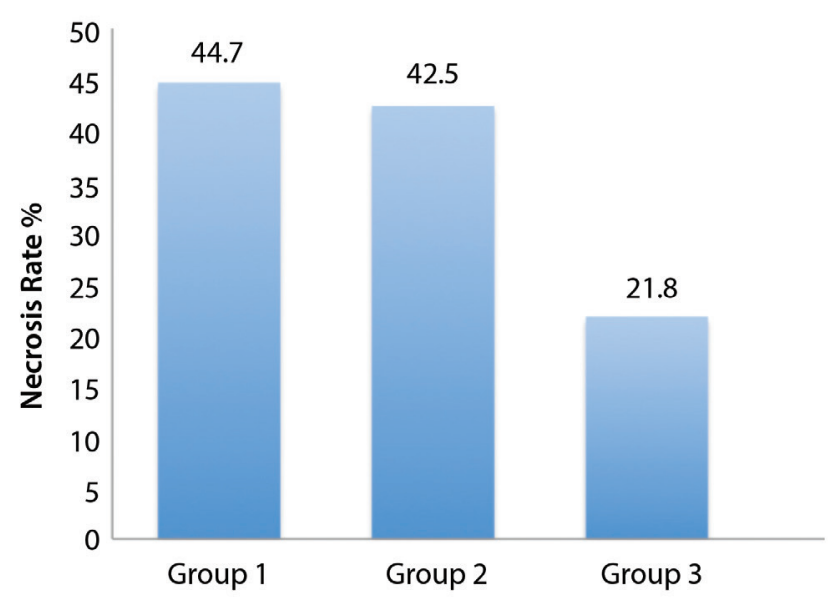

Figure 2. Mean necrosis rate of groups

However, ischemia led to irreversible tissue damage and necrosis at the end of the flap farthest from the pedicle. In the transition zone between these areas, ischemia occurred at early stages due to hyperadrenergic conditions, which were caused by noradrenaline being released from the sympathetic nerve endings and intersecting during flap removal. Perfusion was regained 12 to 24 hours after the hyperadrenergic conditions ended. Reperfusion after the ischemic period causes IR damage (10).

The main reason for IR injury is high levels of ROS and neutrophil chemotaxis. ROS plays a fundamental role in the physiopathology (2) because they have one more unpaired electron on their outer orbits and thus are unstable. These unpaired electrons are ready to react with other molecules to become stable (11). ROS damages DNA by oxidizing nucleic acids, impairs protein structure by oxidizing amino acids and causes lipid peroxidation by reacting with fatty acids (12). The major source of ROS during ischemia is the xanthine oxidase system in the endothelium, which has been shown to be more active in skin flaps during ischemia (2).
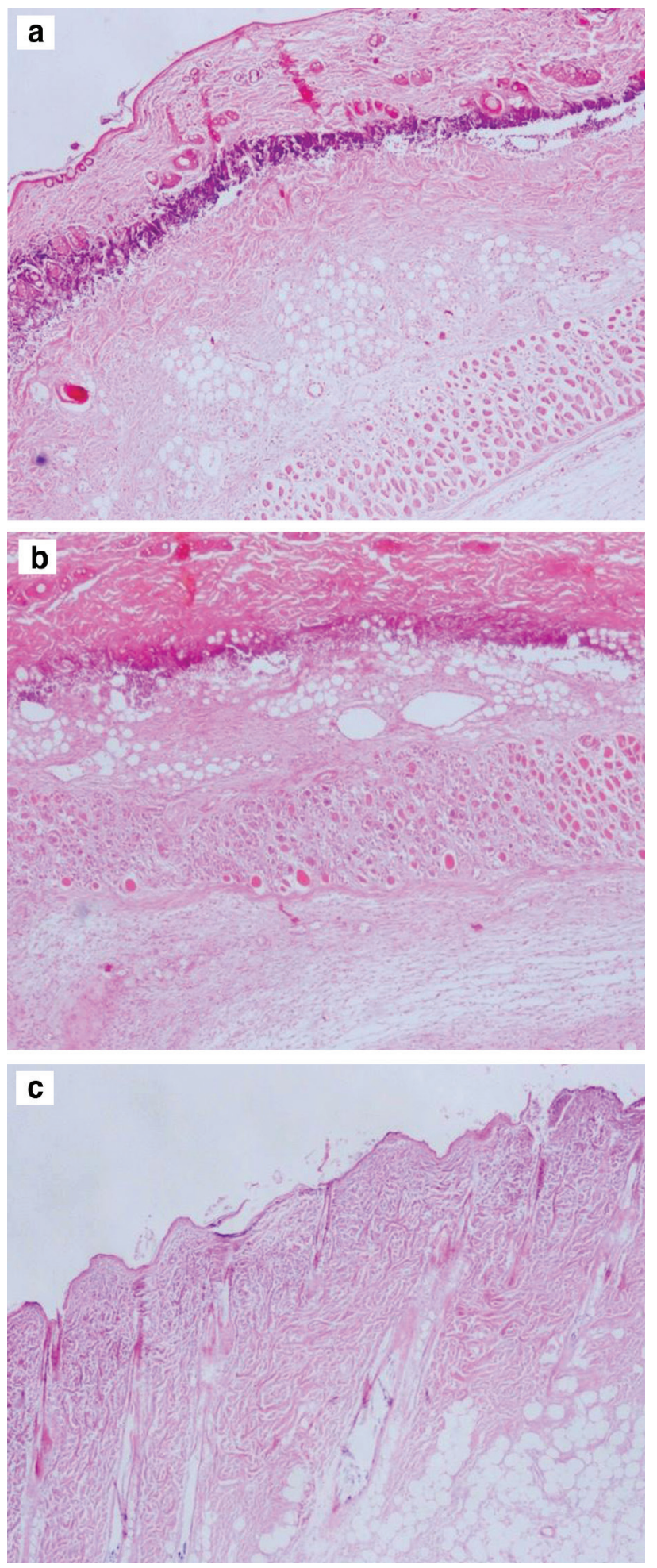

Figure 3. Histopathological views. a. 1 Vascular proliferation and 3 polymorphonuclear cells in the dermis in group 1 (only flap I group), H\&E x40. b. 1 vascular proliferation, 2 polymorphonuclear cells in group 2 (nitrofurazone group), H\&E x40. c. 1.5+ vascular proliferation, 0 polymorphonuclear cells in the dermis in group 3 (QCW group), H\&E x40 
Quercus species are rich in phenols especially flavonoids, condensed tannins (proanthocyanidins), and hydrolyzable tannins (5). Tannins donate electrons to the ROS to stabilize them (13). Bagci et al. (14) showed that proanthocyanidin was a more powerful antioxidant than vitamins $E$ and $C$. Tannins also may exert antioxidant effects by inhibiting enzymes that form free oxygen and nitrogen radicals such as peroxidase, lipooxygenase, iNOS, and xanthine oxidase (15). Furthermore, several studies have shown that tannins reduce neutrophil chemotaxis and inflammation (16). Due to their antioxidant and anti-inflammatory properties, tannins reduce IR injury in the heart muscle, neurons, and skin (17).

Q. coccifera extract has high levels of tannins (5). Our previous study showed that water extracts of Q. coccifera stems exhibit antioxidant activity against NO, superoxide, and 2,2-diphenyl-1-picryl-hydrazyl radicals. The activity levels were similar to those of ascorbic acid and quercetin (6). In the present study, neutrophil chemotaxis was significantly lower in group 3, demonstrating the anti-inflammatory effects of the QCW extract. Our study shows that QCW extract improves flap viability by reducing IR injury in the stasis zone of the flap. Group 3 had lower levels of neutrophil chemotaxis while there was no difference between groups 1 and 2 in vascular proliferation.

Rohrich et al. (18) suggested that an ideal pharmacological agent for making flaps more viable should be effective in the postoperative period, easy to apply, reliable, and cheap. It should also protect against flap necrosis and have a clearly described mechanism. The water decoction of $Q$. coccifera has been used in traditional medicine for centuries and can be considered reliable (19). Herbal products can be prepared easily and cheaply when water is used as the extraction solvent. Our study used it in the same way so it could be applied very easily.

\section{Study Limitation}

In the present study, we only examined a single issue, necrosis area in skin flaps. We did not look at other parameters. This study should be treated as a preliminary study, and further research is needed.

\section{Conclusion}

Necrosis in randomly-patterned skin flaps was significantly reduced with an extract of $Q$. coccifera. We believe that the extract, which is used in traditional herbal medicine, meets all the requirements of an ideal pharmacological agent for skin flap treatment (18). After further research, this extract may be introduced to clinical practice.

\section{Acknowledgments}

The authors would like to thank Pharmacist Isa Arı for sample collection.

\section{Declaration of Conflicting Interests}

The authors declare no potential conflicts of interest with respect to the research, authorship, and/or publication of this article.

\section{Funding}

The authors received no financial support for the research, authorship, and/or publication of this article.

\section{Authorship Contributions}

Concept: E.O., I.Ö.A., A.K.U. Design: E.O., I.Ö.A. Data Collection or Processing: E.O., I.Ö.A., A.K.U. Analysis or Interpretation: E.O., I.Ö.A., B.Y., E.B. Literature Search: E.O., I.Ö.A. Writing: E.O.

Conflict of Interest: No conflict of interest was declared by the authors.

Financial Disclosure: The authors declared that this study received no financial support.

\section{References}

1. Orhan E, Erol YR, Deren O. Efficacy of Liposuction as a Delay Method for improving flap survival. Aesthetic Plast Surg 2016;40:931-7.

2. van den Heuvel MG, Buurman WA, Bast A, et al. Review: Ischaemia-reperfusion injury in flap surgery. J Plast Reconstr Aesthet Surg 2009;62:721-6.

3. Orhan E, Uysal AÇ, Başer E, et al. The effect of intradermal administration of inactive platelet-rich plasma on flap viability in rats. Acta Cir Bras 2017;32:280-6.

4. Khennouf S, Benabdallah H, Gharzouli K, et al. Effect of tannins from Quercus suber and Quercus coccifera leaves on ethanol-induced gastric lesions in mice. J Agric Food Chem 2003;51:1469-73.

5. Söhretoglu D, Kuruüzüm-Uz A, Simon $A$, et al.. New secondary metabolites from Quercus coccifera L. Rec Nat Prod 2014;8:323-9.

6. Genç $Y$, Yüzbaşıŏlu M, Harput Üş. Antioxidant Activity and Total Phenolic Content of Quercus coccifera L. FABAD J Pharm Sci 2012;37:17-22.

7. Orhan E, Yüzbaşıoğlu M, Erol YR, et al. The effect of Arnebia pupurea extract on the survival of random pattern skin flaps in rats. Eur Res J 2018;4:152-6.

8. Wang SP, Lan ZY, Xia W, et al. The effects of vasonatrin peptide on random pattern skin flap survival. Ann Plast Surg 2014;72:94-9.

9. Uysal AC, Mizuno $H$, Tobita $M$, et al. The effect of adipose-derived stem cells on ischemia-reperfusion injury: immunohistochemical and ultrastructural evaluation. Plast Reconstr Surg 2009;124:804-15. 
10. Cymrot M, Percario S, Ferreira LM. Oxidative stress and total antioxidant status in ischemic skin flaps in rats. Acta Cir Bras 2004; 19:18-26.

11. Reilly PM, Shiller HJ, Bulkley GB. Pharmacologic approach to tissue injury mediated by free radicals and other reactive oxygen metabolites. Am J Surg 1991;161:408-503.

12. De Celle T, Cleutjens JP, Blankesteijn WM, et al. Long-term structural and functional consequences of cardiac ischaemiareperfusion injury in vivo in mice. Exp Physiol 2004;895:60515.

13. Soobratteea MA, Neergheen VS, Luximon- Ramma A, et al. Phenolics as potential antioxidant therapeutics agents: mechanism and actions. Mutat Res-Fund Mol M 2005;579:200-13.

14. Bagchi D, Garg A, Krohn RL, et al. Oxygen free radical scavenging abilities of vitamins $C$ and $E$, and a grape seed proanthocyanidin extract in vitro. Res Commun Mol Pathol Pharmacol 1997;95:179-89.
15. Ishii R, Saito K, Horie M, et al. Inhibitory effects of hydrolyzable tannins from Melastoma dodecandrum Lour. on nitric oxide production by a murine macrophage-like cell line, RAW264.7, activated with lipopolysaccharide and interferon-gamma. Biol Pharm Bull 1992;22:647-53.

16. Mandel S, Youdim M. Catechin polyphenols: neurodegeneration and neuroprotection in neurodegenerative diseases. Free Radic Biol Med 2004;37:304-17.

17. Karaaslan O, Ulusoy MG, Kankaya Y, et al. Protective effect of grape seed extract against ischaemia/reperfusion injury. J Plast Reconstr Aesthet Surg 2010;63:705-10.

18. Rohrich RJ, Cherry GW, Spira M. Enhancement of skin flap survival using nitroglycerin oinment. Plas Recon Surg 1984;73:943-8

19. Şöhretoğlu D, Sakar, MK. Quercus türlerinin polifenolik bileşikleri ve biyolojik aktiviteleri. J Fac Pharm Ankara 2004;33:183-215. 